
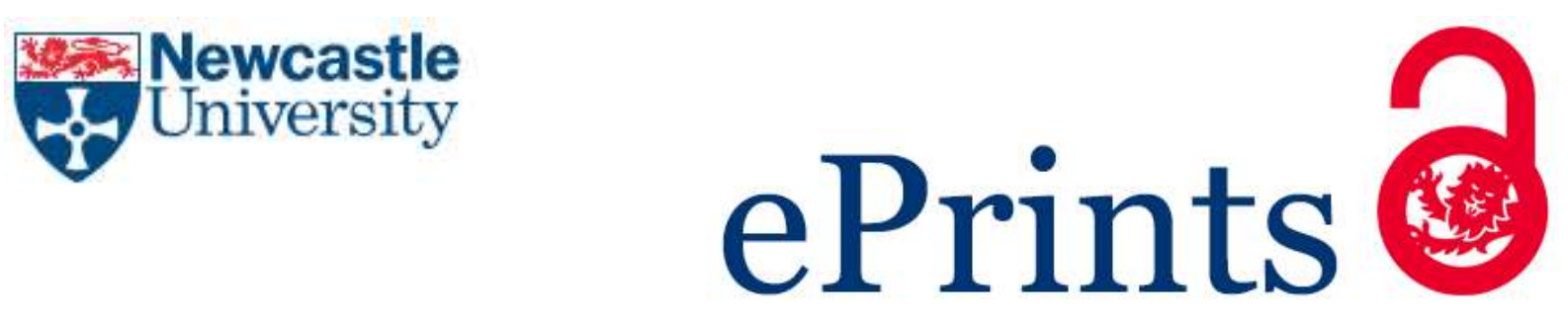

Morton A. Popery, Politics and Play: visual culture in Succession Crisis England. The Seventeenth Century 2016

\title{
Copyright:
}

This is an Accepted Manuscript of an article published by Taylor \& Francis in The Seventeenth Century on 29-11-2016, available online: http://dx.doi.org/10.1080/0268117X.2016.1237885

Date deposited:

$29 / 11 / 2016$

Embargo release date:

18 May 2018

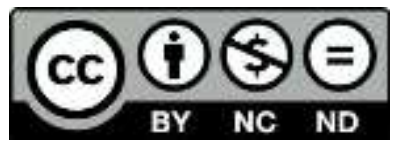

This work is licensed under a

Creative Commons Attribution-NonCommercial-NoDerivatives 4.0 International licence 


\section{Popery, Politics and Play: visual culture in Succession Crisis England}

The study of seventeenth century visual culture has flourished in recent years. Helen Pierce, Mark Knights and Kevin Sharpe have been attentive to the role of the visual in political discourse, placing graphic satires within the seventeenth century's expanding news culture and demonstrating the extent to which visual sources were indebted to and parasitic upon other media. ${ }^{1}$ Borrowing their motifs from plays, pamphlets, and ballads, graphic satires responded to and commented upon specific political moments and particular political ideologies in much the same manner as other genres of news media. ${ }^{2}$ If historians have demonstrated that barriers between media were porous - stressing continuity over change and interaction over obsolescence in the relationship between oral and printed cultures - then the osmosis of ideas and attitudes which they have charted must be extended into the visual sphere, too. ${ }^{3}$ In this regard, graphic satire is presented as another aspect of political "representation" in a nascent public sphere. ${ }^{4}$ Here, as in texts, authority was propounded, contested, and debated; and here, as in texts, an ever-widening political public was invited to respond to ideas and events through their presentation in ideological forms. ${ }^{5}$ Political ideas were not encountered in pure, nonpolemical contexts. That the ways in which they were presented to and debated by the public were as important to the political process as the ideas themselves is an historiographical truism - graphic satire, as another aspect of political representation, is now recognised as an important strand of that expansion. ${ }^{6}$

Figure 1. Roger L'Estrange, The Committee, or Popery in Masquerade (1680). Copyright of the British Museum. 
Such perspectives are salutary. But they risk downplaying the graphic element of graphic satires by over-integrating them into news discourse. In arguing that material traditionally neglected by historians should become part of the discipline's mainstream body of sources, these scholars have stressed the points of contact which graphic satires had with those (primarily textual) sources at the expense of determining what made them distinct. ${ }^{7}$ What did the graphic add to political discourse which other media could not? Some historians have been sensitive to this question. Graphic satires are often depicted as blanket "propaganda" akin to modern political posters, distilling a "party" position formulated elsewhere to a broader audience in a crisply condensed manner. ${ }^{8}$ Thus Tim Harris suggests that one of the period's most famous prints, Roger L'Estrange's The Committee; or, Popery in Masquerade (1680), simply "encapsulated the Tory case" that the Whig's drumming-up of anti-Catholicism to lobby for alteration of the Succession was actually a mask for their true desire to abolish monarchy and plunge the realm back into civil war [Fig. 1]. ${ }^{9}$ The Committee certainly reflected these general themes of Tory ideology. Yet it was not simply a translation of some other discourse into visual form, but rather an independent form of discourse in its own right. It was a highly focussed riposte to the Whig satires of Stephen College surrounding agitation for Charles to call Parliament in early 1680. Rather than resting upon a blanket "Tory" line, The Committee was a precise intervention in a moment of politics. Its commentary was focussed rather than generic, and depended upon audiences grasping the biting subtlety of its allusions to College's satire. ${ }^{10}$

Accentuating this pointedness is important if we are to understand the roles which graphic satires played in political culture. Reading satires simply as political posters suggests a decidedly top-down (or at least centrally organised) approach to the political press which robs the voices of individual satirists of agency. Moreover, characterising prints as simply expounding "party" positions to "those on the margins of literacy" suggests a highly passive 
form of reading. ${ }^{11}$ Conversely, as Kate Loveman has demonstrated, this period was marked by active readers hungry to grapple with texts. ${ }^{12}$ As highly detailed and acutely acerbic demonstrations of rhetorical skill, graphic satires appealed to this form of readership. ${ }^{13}$

This is not to deny that some viewers undoubtedly did read prints like The Committee as political posters or synopses of party positions as Harris suggests. Christopher Marsh's work on ballads has stressed their ability to be read in different ways by different audiences. The level of prior knowledge of the associations tied to a ballad's tune, or prior use of its images, affected consumers' ability to unlock meanings, and the status of a given ballad - its "meaning" - was therefore inherently turbulent rather than fixed. ${ }^{14}$ The afterlife of some seventeenthcentury prints long after their political moment had passed similarly suggests that audiences reacted to them in ways which their creators could not have intended. Indeed, as Sharpe has noted, the political strength of visual sources rested on their ambiguity, their capacity to engage audiences of differing political sophistication in different ways. ${ }^{15}$ It is thus undoubtedly true that some reader/viewers experienced graphic satires as distillations of party ideology. The point made here is that such prints were not intended to be political posters in this way. They rarely informed audiences of anything new, but provided witty commentary on what was already known. The range of allusions left un-expounded, asides left unexplained and the minutiae of events referred to suggest those who commissioned graphic satires expected highly-literate knowing reader/viewers.

Suggesting that the intended audience was politically literate is not to limit graphic satires to the social elite. The expansion of news media during the Restoration meant that authors of genres with a wide social readership - pamphlets, ballads, newssheets - expected a wellinformed audience conversant in day-to-day politics, and assumed familiarity with the developments which they commented on. ${ }^{16}$ Graphic satires shared this knowingness with other forms of print. It is argued here that this assumption of knowledge - this space to comment 
rather than inform - was essential to the nature of the relationship between creator and audience which graphic satire cultivated. That relationship was playful. Dependent upon close-reading, audiences entered a game with the creator: as their intelligence was flattered by recognising the satires' array of allusions so they fostered appreciation of the commentary's skilfulness essential to increasing the appeal of its political points.

This article argues that the intimacy which emerged from this playfulness was vital to graphic satires' ability to provide acute intervention in a given political moment. Two points are made. First (as other scholars have noted) graphic satires' content and polemical strategies were heavily intertwined with wider news discourse; and, second, they must nevertheless be understood as graphic products which responded to that news discourse in enticingly playful ways. That playfulness afforded prints space to commentate upon and expose the strategies of other media and, by doing so, to undercut those media's effectiveness as political commentary. These points are demonstrated by analysis of Tory graphic satires' use of parody to rebut Whig use of the 'Popish Plot' as a vehicle of oppositional politics. The Whigs used visual culture to forge a powerful anti-Catholic brand which solidified pro-Exclusion protest in a performative manner. This was best demonstrated in the Pope-burning processions which snaked their way through London's streets in November 1679-80. This imagery of martyrdom, conspiracy and Jesuitical machination was saturated in post-Reformation society at the point of assumption, and in utilizing it the Whigs spun the memory of England's anti-Catholic past behind the lobby for political reform in the present. ${ }^{17}$ The familiarity of this imagery was vital to Tory satires' ability to ape and parody it: their playful engagement with it was the source of their polemical attack. In this way, the graphic element of graphic satire - its capacity for deception and parody - is foregrounded as central to both its appeal to audiences and its political power. 


\section{II: Visual Culture and the Popish Plot}

The Popish Plot articulated the clichés of seventeenth-century anti-Catholicism. ${ }^{18}$ Invented in 1678 by Titus Oates - who claimed to have infiltrated the Jesuits and discovered letters detailing a plot to assassinate Charles II, burn London (in emulation of the 'Catholic' Fire of 1666), and restore Catholic dominion in England - the plot was to be orchestrated by five Catholic peers under nebulous Papal/Jesuit leadership. ${ }^{19}$ As one Privy Councillor noted, Oates's depositions were "a loose and tottering fabric which would easily tumble if stood alone". ${ }^{20}$ Two coincidences garnered them credibility. First, one of the accused, Edward Coleman, secretary to the Duke of York's wife, had written to Louis XIV's confessor concerning England's re-conversion - his execution for treason in 1679 only made Oates's tapestry of accusations seem more real. ${ }^{21}$ Second, the mysterious murder of Edmund Godfrey, the magistrate who had taken Oates's depositions. ${ }^{22}$ This murder was spun into a conspiracy. Offers of substantial rewards for information led to other "witnesses" - most noticeably William Bedloe and Miles Prance - emerging to compete with Oates. Their provision of macabre details of Godfrey's execution by Jesuits in revenge for Oates/Godfreys" “discovery” of the Plot led to their becoming (with Oates) the focal-points of a series of sensational Catholic trials in $1679 .{ }^{23}$ These trials rapidly became causes célèbres, with newspapers readily charting their process, coffee houses acting as the site of their dissection, and verbatim accounts pouring off the press at their conclusion.

The Plot was also timed fortuitously. In 1673 the heir, James, Duke of York, converted to Catholicism. For many groups, the prospect of Catholic Succession assaulted two hallmarks of Englishness: Protestantism and parliamentary liberty. "Popery" had been the nemesis of the former - and England's Antichristian enemy - since the Reformation; and, in the wake of the “Catholic" style of absolutist government typified by Louis XIV's France, it now represented the antithesis of the latter. ${ }^{24}$ Combined with the increasingly "arbitrary" manner of Charles' 
government, James' conversion triggered a series of complex constitutional disputes often termed the "Succession Crisis". ${ }^{25}$ A nascent Whig party lobbied for a series of constitutional changes - ranging from James' outright exclusion from the throne in favour of a Protestant candidate, to a severe limitation of his monarchical rights - by which greater parliamentary power would be effected. Oates's farcical plot aided the Whigs immensely: it made Catholicism's threat seem immediate and tangible; and created a situation in which one could both oppose the monarchy (by pursuing constitutional change) and be loyal to it (because in the face of the plot doing so was the best means of safeguarding Charles II). The Whigs were not alone is making political hay out of conspiracy, however. Tory opponents of the Exclusionlobby claimed that the later manipulated anti-Catholic fears engendered by the plot to overthrow the monarchy in a re-playing of $1641 .{ }^{26}$ One plot countered another.

Evaluating political claims in this factious and fractious atmosphere was difficult. As Mark Knights has demonstrated, contemporary fears about the presses' mendacity increased during this period. This posed a substantial problem at the moment when the political process became increasingly representational. Appealing to the public through increasingly frequent elections, petitions, and the informal politicization of the press, each party routinely addressed the populace and claimed to best represent its interests. Yet this deference to the public as political umpire sat uncomfortably with increased fears of its ability to judge rationally and properly. ${ }^{27}$ Fears that popular opinion could easily be skewed by the press's perfidious capacity for misinformation were exacerbated by the inherently conspiratorial nature of party politics in which malicious manipulation of "Truth" to party ends was endemic. Volumes of contradictory rhetoric not only made it difficult to judge where truth lay in an absolute sense: it led to partisan affiliation becoming the determinative authority of what individuals held to be true. Those affiliations were sustained by textual communities driven by a party-leaning press. ${ }^{28}$ 
The Popish Plot's media - a melee of accusations and counter-accusations - expressed this crisis of political representation and misrepresentation perfectly. Following the collapse of licensing in 1679 issues surrounding James' succession were debated in a surge of print. ${ }^{29}$ The Plot trials' minutiae formed important focal-points upon which pro- and anti-Exclusion ideologies clashed, with each wrestling to control their interpretation by poring over the trials of the accused in well-nigh fetishistic detail. Each party used slogans to puncture the resulting confusion. As ensigns, "Liberty", "Arbitrary Government", "41 is come again", and "Popery" reduced complex issues to emotive impulses behind which political groups solidified. ${ }^{30}$ Here forceful representation of political ideas - rather than the ideas themselves - was vital to the momentum of political lobbying, for these slogans' imprecision provided suitably flexible banners behind which support could crystallise. Slogans may have been magnetic, but their rhetorical openness was dangerously malleable. Concerns that rhetoric hampered the public's ability to judge by allowing ideology to become increasingly divorced from reason were prevalent. As Robert South, chaplain in ordinary to Charles II, noted in 1686: "words are able to persuade men out of what they find and feel, to reverse the impression of sense....the greatest affairs and most important interests of the world, are carried on by things not as they are, but as they are called." 31

Figure 2. England's Grand Memorial (1680). Copyright of the British Museum.

Figure 3. A Representation of the Popish Plot in twenty-nine figure (1679). Copyright of the British Museum.

Such anxiety was a back-handed compliment to rhetoric's steering power. Anti-Catholic images could play a similarly emotive role in Succession Crisis media, distorting events to 
unify opinion behind them. ${ }^{32}$ A multi-media imagery prevalent across printed and material culture, anti-Catholicism became, in essence, a badge of oppositional allegiance, a brand of Exclusion which was iconographically consistent across print, the pope-burning processions, playing cards, and ceramics. Its power to crystalize party feeling rested upon resonances accrued through repetition. ${ }^{33}$ Amidst the mass of evidence, accusations, and counteraccusations circulating in news discourse, key moments of the plot - such as Godfrey's murder, to the failed attempt to shoot Charles in St. James's Park reported by Oates - became iconic. They emotionalised and condensed religio-political values in much the same way as slogans. But by making these scenes iconic, repetition also created and sustained narratives. Understanding that this anti-Catholic brand's relationship with wider news discourse was simultaneously parasitic and reflective is vital to comprehending this. Graphic satires extrapolated events and information from the wider news discourse. In doing so, they made the aspects extrapolated more visible in that discourse as a form of short-hand for the plot. The mass of information Bedloe and Prance provided about Godfrey's murder, for example, was codified into four key scenes common across visual/material culture: his Jesuit assassins luring Godfrey, as magistrate, to intervene in a staged street-brawl; their subsequent ambush and murder of Godfrey; his corpse being propped-up on horseback and transferred to Somerset House; and its removal to Primrose Hill in a sedan several days later. ${ }^{34}$ Each element of this narrative was instantly recognisable through a stock depiction. Other aspects of the plot were given similar treatment in visual media, which centred upon storyboard prints "telling" the Plot's story through a series of events pulled together from various witness accounts, as examples like The Catholick Gamesters (1681), The Popish Damnable Plot (1680), England's Grand Memorial (1679) [fig. 2], and A Representation of the Popish Plot in twenty-nine figures (1681) [fig. 3] demonstrate. ${ }^{35}$ Here a plot blueprint was condensed, framed, and legitimated through repetition. 
These storyboard prints attempted to fix $a$ narrative of the plot out of the nebula of conflicting information/misinformation which the trials and other commentaries spewed into the public sphere. They were a form of laundering by which accusations were cleansed of their problematic/qualified status to become unproblematic "information." This rested upon divorcing events/information from their original contexts (as part of subjective/contested witness reports) and injecting them into another (as part of a seemingly objective illustrated record of "the Plot") to create an authoritative Whig narrative. The processes by which that information came to appear before the public are hidden. Thus A Representation of the Popish Plot [fig. 3] appears to display an uncontested metanarrative, but actually draws upon multiple fragments of information drawn from accounts by Titus Oates, William Bedloe, Miles Prance and various of the plot trials: what was in reality a mosaic of accusations is presented as an accurate rendering of events. ${ }^{36}$ This was issued in 1681, when the Whigs' cause was waning. The images added moments concurrent with its publication (Stephen Dugdale's emergence as a star witness and the execution of Lord Stafford) to a cluster of scenes which had become iconic in recent years - such as Godfrey's murder - to give the sense that the Plot was still unfolding and therefore that Exclusion was still alive as an urgent political issue. In The Protestant's Vade Mecum (1682) - an anti-Catholic emblem book - the Plot's storyboard is the culmination of a longer (and widely accepted) narrative of Papal-inspired malevolence against England dating back to the 1534 Act of Supremacy. ${ }^{37}$ Here the Popish Plot (1678) was the next footstep following the Armada (1588), Gunpowder Plot (1605) and Irish Massacres (1641).

Figure 4. A True Narrative of the Horrid Hellish Popish Plot - part 1 (1682) Copyright of the British Museum. 
Figure 5. A True Narrative of the Horrid Hellish Popish Plot - part 2 (1682). Copyright of the British Museum.

\section{III: Visual Deception and Shamming}

The effectiveness of this storyboard imagery is demonstrated by Tory parodies which sought to undermine it. A True Narrative of the Horrid Hellish Popish Plot (1682) - a two-part graphic satire issued by an anonymous author/artist - parodied storyboard imagery to expose the strategies by which the Whigs had represented the Plot to the public [figs $4 \& 5$ ]. Its intervention in politics rested on its playfulness. It utilized deception - aping the storyboard prints to be taken for once at face value - to expose the deceptiveness of what it satirised. Reader/viewers' enjoyment of the satire thus depended on their being shammed into thinking that this was another exposition of the plot. The prints' title directly echoed Oates's publication of his depositions, True and Exact Narrative of the Horrid Plot and Conspiracy of the Popish Party (1679) and their images and verses initially purported to support prosecution of the plot before mocking the evidence on which it was based. Horrid Hellish Popish Plot's playfulness was thus the nub of its disruptive intervention into public discourse: it re-framed the object of its parody (Whig graphic satire) through laughter. It is argued below that parody acknowledged the roles which Whig graphic satire had played in oppositional politics and dampened its force by exposing its polemical strategies as manipulative of public opinion. These prints' graphic playfulness - their capacity to sham Whig polemic - was essential to their polemical power.

Their remit, however, spread far wider than the purely graphic elements of Whig polemic. The Horrid Hellish Popish Plot's confident, multi-faceted approach to print-making suggests that it was designed to cater for a highly informed audience familiar with pro-Exclusion graphic satire. There was a mass of material here. Reading these prints was no linear experience information was not absorbed in a line by line, left-to-right, process but in a teasing and 
exacting manner, with reader/viewers moving back-and-forth between the images and myriad of surrounding texts to slowly unravel the prints' series of polemical barbs. Each of the prints contained twelve images (accompanied by mocking captions); ${ }^{38}$ verses relating to those images (previously issued as a ballad); and (on the sides) a series of references to pivotal points in the printed Plot narratives and trials which were being satirised. ${ }^{39}$ This was the only seventeenthcentury print to be footnoted. Tracing the spotlight over gaping holes in the "Popish Plot" narrative, and mocking forms of academic truth telling to draw reader/viewers' attention to the specious absurdities of the witnesses' claims, these prints ultimately highlighted that the Plot rested upon a foundation which could not bear its weight. The footnotes were significant: audiences were not only asked to engage in sophisticated practices of reading within these prints, but to refer back to other printed media, to re-read plot and trial narratives in light of its satire. Whig media were thus re-framed through parody: once reader/viewers "got" the sham a reversal took place in which Horrid Hellish Popish Plot became the background text against which the Plot was read when they re-encountered the Whig media which it cited. ${ }^{40}$ These prints suggested that the true perfidy at work in Restoration society was not Catholic conspiracy, but the specious manipulation of anti-Catholic sentiment to endanger the crown.

This was a familiar theme of the Tory revival in politics during the early 1680s, which marked the re-assertion of crown control and the decline of effective lobbying for constitutional reform by the Whigs. ${ }^{41}$ That revival was achieved through a balance of policy and police. Charles II's dissolution of the third Exclusion Parliament (March 1681) ushered in a period of personal rule which lasted until his reign ended. ${ }^{42}$ Put simply, no parliament meant no avenue for constitutional change. Personal rule was accompanied by a purge of local government which thrust Whigs from office; ${ }^{43}$ and interference in local elections ensured that Parliament was staffed with loyalist MPs. Yet the fact that the crown had to pursue persuasion - that state power was not enough to quash pro-Exclusion momentum - testifies to the public sphere's 
vitality in the political process. ${ }^{44}$ The Tories matched the Whig campaign of street politics/protest with their own chorus of pro-crown bonfires and bells; ${ }^{45}$ and parried Whig petitioning campaigns with a campaign of loyal addresses. ${ }^{46}$ The press proved particularly potent. The Tories matched the Whigs in breadth of audience. ${ }^{47}$ The learned were engaged via lengthy treatises on political thought, pamphlets targeted wider audiences, newspapers controlled the day-to-day interpretation of events, and songs and satires rivalled Whig polemic's raucousness. ${ }^{48}$ Invective did not just claim that Exclusion was unlawful. Asserting that it would cripple the realm, it cast the Whigs, not Catholic Succession, as the true threat to England's liberties because they pursued a policy which could only re-ignite Civil War. ${ }^{49}$

Detail figure 4.1: Godfrey being murdered in The Horrid Hellish Popish Plot (1682)

Figure 3.1: Godfrey being murdered in A Representation of the Popish Plot in 29 Figures (1678-81).

Detail figure 4.3: Whilst transporting Godfrey's corpse from Somerset House to Primrose Hill, his Jesuit assassins miraculously bend and straighten the limbs of a man dead for several days. In the background, Godfrey's corpse is run through on Primrose Hill. The Horrid Hellish Popish Plot (1682)

Figure 2.1: Godfrey's corpse run through on Primrose Hill in England's Grand Memorial (1679) 
Horrid Hellish Popish Plot initially seemed to detail Catholic perfidy in a manner typical of pro-Exclusion prints. It promised to tell how "the Jesuit, Devil and Pope did agree/ Our state to destroy. ${ }^{, 50}$ Depicting key scenes from the Plot in a manner which echoed Whig media was crucial to the ruse: thus scenes of Godfrey being murdered mirrored Whig graphic satire iconic images of his being strangled and run-through with his own sword are very similar in the Whig original and the Tory parody [figs 4.1-4.3 and 2.1 and 3.1]. ${ }^{51}$ The ploy encouraged unsuspecting readers to agree with the print before reversing its message: it was ultimately the witnesses (Oates and Bedloe) who were deemed dishonest here: ${ }^{52}$

To comfort our Doctor, brave Bedloe's brought in,

A more Credible Witness was not above ground;

He vows and protests, though a Rogue he had been,

He wou'd now not swear for Five Hundred pound [his state pension as a 'witness'];

And why should we fear

They falsly would swear,

To damn their own souls, and lose by it here.

Poor Oat, who before had no Penny in Purse,

Discov'ring the Plot, was seven hundred pound worse.....'

Prance's evidence concerning the murder of Godfrey was mocked as farce:

His Body they toss'd

From pillar to Post,

And shifted so often,

'thad like t'have been lost. ${ }^{53}$

The footnote to this verse (and the accompanying image) referred to printed accounts of the trial of Godfrey's Jesuit “murderers". It focussed on Prance's evidence concerning their 
moving his corpse - and exhibiting it to Catholics in a ghoulish celebration of the Plot's beginning - all over Somerset House. Prance recounted how Godfrey was murdered on a Saturday and his corpse stowed in Lawrence Hill's (one of the Jesuits) rooms until Monday, when it was moved to Somerset House, before returning to Hill's on Tuesday. When one of the judges noted that Hill's rooms were actually in Somerset House (thus rendering his account illogical) Prance became flustered, said he could not remember its whereabouts precisely because it was dark - “.....and shifted so often, "thad like t'have been lost", scoffed the print. ${ }^{54}$ What had been a revelation in court was now the source of a mendacious farce. Exploiting fissures in the surface of the dominant Whig discourse of the Plot, these prints made their presence felt in the political sphere. In this way, Horrid Hellish Popish Plot demonstrates graphic satire's capacity to contribute to the Tory turn in news media during the early 1680 s.

\section{Detail figure 4.2: Oates fainting before the Privy Council to cover contradictions in his narrative of the plot.}

Detail figure 4.4: The Jesuit assassins manage to pass unseen from Somerset House, despite the presence of a sentry (who had no recollection of seeing a sedan chair pass the main gate). Here, a devil covers the sentry's eyes to explain the gap in Bedloe's evidence.

Each of the twenty four images point to holes in the witnesses' accounts. Acting as hooks which led reader/viewers to a mocking verse, and then (through the footnotes) out from the satire into the web of discourse by which the plot had been sustained, they honed-in on particular flimsy strands of evidence. ${ }^{55}$ Scene nine of the second print depicted Oates "fainting" before the Privy Council when he could not recognize Edward Coleman (whom he had claimed to have seen at a Jesuit cabal). References point reader/viewers to Oates's farcical later assertion that the lighting had been too poor for him to recognize Coleman [fig 4.2] ${ }^{56}$ Honing-in on unfeasible elements of the witnesses' depositions created a counter-narrative which checked proExclusion polemic by highlighting that accepting the Plot demanded belief in the incredible at 
the expense of scrutinizing detail. The public was asked to believe: that Godfrey's Jesuit assassins were able to bend the legs of his three-day-old corpse to place it in a sedan chair (to facilitate his transfer from Somerset House), and then straighten them again before dumping him on Primrose Hill [detail fig 4.3]; ${ }^{57}$ that in leaving Somerset House they had passed the main gate without any sentry seeing them (the evidence is mocked in an image of a devil shielding the sentries' eyes as the "murderers" scurry past with Godfrey) [detail fig. 4.4$] ;{ }^{58}$ that the Pope was so incompetent that (following Oates's claims) he intended the Catholic chancellor of England to be Lord Arundel, who had "ne'er studied law", and the general of his invasion force to be Lord Bellayse, who was not only a gout-riddled man in his seventies (pictured on the battlefield with crutches and a resting stool) who had never seen battle ("camp ne're saw") but was known to be an ardent royalist [detail fig. 4.5 ] ${ }^{59}$ and that a force of forty thousand snuck into Ireland untraced - mocked in the print through the hilarious incongruity of an image of an vast army captioned: 'Irish Army. Lies Incognito' [detail fig. 4.6.] ${ }^{60}$

\section{Detail figure 4.5: The Catholic peers - "General" Bellais depicted as decrepit and with a gout stool.}

\section{Detail figure 4.6: The "Irish Army: Lies Incognito."}

This last scene is deceptively simple: closer inspection demonstrates that it expected complex reading practices from the prints' audience. It combines elements from several Plot accounts and getting the joke consequently rested upon audiences bringing considerable prior knowledge to the print. It refers to Oates's claim that the Irish invasion force would be armed with billhooks, and mocks the idea of a vast army being undiscovered, the notion that so many billhooks could be made secretly, and the fact that Oates had no idea where they were made. In the scene, Irish soldiers say "where were these Bills made?", "at Bilboe \& Salamanca." The key $[\mathrm{H}]$ explains the barb: "The Doctor [Oates] does not tell us where these forty thousand bills 
were made; but our reason tells us, that 'twas very necessary they should be hammered as privately as possible (for fear of discovery) and therefore Bilboe and Salamanca, may pass far more probable than London or any town in England." This relates to Oates's testimony at Coleman's trial where he claimed not to have known what bill-hooks were or who provided them for this army despite having read intimate details of the Jesuit's preparation for invasion. Verse X continued the mockery: "To arm well this Host,/ When it came on our coast,/ Black Bills forty thousand are sent by the post,/ This Army lay private'y on the Sea Shore;/ And no man ever heard of them since nor before....." The references cite Richard Langhorn's trial. At the pages in question, Bedloe's claim that Langhorn's letters were crucial in arranging (with Coleman and Harcourt) the co-joining of Irish and Spanish forces is disputed in detail by other witnesses. ${ }^{61}$

This dogged use of references to base these absurdities in the "facts" of the witnesses' accounts was a form of animadversion, the replication of an opponent's text, along with censorious commentary, in an interrogative textual battle. Animadversion had become prevalent during the Civil Wars. Removing information from its original context to make it look absurd was a familiar tactic, and aimed to constrain the way in which the original was read. ${ }^{62}$ Burlesquing the plot by thrusting together the farcical and implausible, Horrid Hellish Popish Plot's parody consequently did more than dampen the plot's credit. It exposed the mechanisms by which proExclusion polemic had sought to make political gains from it (selective presentation of evidence, the invention of a conventional - and therefore credible - Catholic "plot", and appealing to emotive anti-Catholicism to by-pass reason). Using the witnesses' accounts as the basis for farce was essential to these prints' counter-discursive force. Whig discourse was not merely so stylistically mechanical as to be easily parodied, but rather the actual source of the parody's language: referencing pro-Exclusion literature meant that this was not the Plot imitated, but the Plot itself. 


\section{IV: Doubt}

Here Horrid Hellish Popish Plot touched upon wider ideological currents. Anti-popery was a vital language of religio-politics which each side of a given political divide strove to control. As the arbiter of what was true and protestant, anti-popery was a highly malleable ideology. ${ }^{63}$ Although always the antithetical other against which protestant verity was defined, what constituted Popish otherness shifted in relation to whether that verity was Arminian or Puritan, Parliamentary or Royalist, Whig or Tory. ${ }^{64}$ Scott Sowerby has shown that there was a growing recognition in Restoration society that this malleability was dangerous because it was repeatedly used to position the church and crown as other to Englishness and Protestantism. ${ }^{65}$ Opposing anti-popery required the striking of a precarious balance: authors strove to contest their opponent's definition of what was popish or how extensive the current threat of popery was, without appearing to reject anti-popery as the moral baseline and constitutional ideal of English society. During the Succession Crisis Roger L'Estrange, the crown's chief polemicist, adopted a line which neutered the Plot as a vehicle mobilising support for constitutional change and situated the Tories as the true stalwarts against popery. ${ }^{66}$ L'Estrange never denied that a Plot had existed, but charged firstly that it had been curtailed. Secondly, he argued that Whig attempts to manipulate the constitution by fomenting anti-Catholic panic was itself a "popish" conspiracy against church and state: for, like the Pope, they hoped to see the crown overthrown. ${ }^{67}$ Exposing the opposition thus rested upon appropriating its language.

\section{Detail figure 5.1: The execution of the Jesuit "assassins."}

Horrid Hellish Popish Plot walked an equally fine line. Exposing the cracks in Bedloe's evidence against the Jesuits executed for "murdering" Godfrey was not coupled with any suggestion that the latter were martyrs. Indeed, the prints included a ghoulish depiction of their 
execution [fig 5.1.] ${ }^{68}$ The Jesuits protest their innocence, but the caption - "And to be cut into fowre Quarters/ Cause they'd be Canoniz'd for Marters" - mocks the "Catholic" equation of regicide and salvation in a manner commonplace in anti-Catholic polemic. Avoiding their diminishing of the Plot collapsing into a pro-Catholic apology, these prints - like much Tory literature - balanced exposure of the opposition's (excessive) anti-Catholicism as manipulative of public opinion with an appropriation of that language as the proper discourse of politics. Parody neutered anti-popery by exposing the mechanisms by which it was drummed-up. Here satirical irony reached its apogee. The Exclusion lobby styled itself as a defence of England's religion and liberties against popery, an unceasing assault on the protestant state and church. But by excavating the specious basis of the current "No Popery" hysteria Horrid Hellish Popish Plot's sham demonstrated that anti-popery could be an equally mendacious fog on English sensibilities. Subjecting the audience to one sham (the prints' deceptive parody) revealed that they were the victims of another (at the hands of the pro-Exclusion lobby). One artifice exposed another: graphic playfulness and polemical force were entwined.

Much of this complemented general themes of Tory media. Indeed, the view that the Whigs manipulated public opinion by fomenting anti-Catholicism, and that this masked a desire to overthrow monarchy as it had done in 1641 , was so ubiquitous that it was condensed into a slogan: "41 is come again." 69 It is thus undoubtedly true that Tory reader/viewers would certainly have found their views reinforced in Horrid Hellish Popish Plot. But the prints did not bluntly tie themselves to this line, nor were they explicitly anti-Exclusion or pro-Yorkist. As such, they were not a distillation of "party" lines or crude, expository "propaganda". Such a characterisation depicts graphic satires propounding pre-formed opinion rather than contributing to that opinion's formation. Their power lay in the subtlety of their attack: by forcing them to re-read works cited and re-consider the visual culture which saturated news media, satire here teased audiences into thinking rather than telling them what to think. The 
tone throughout is one of mocking doubt which simply prodded reader/viewers to reconsider through an incessant line of questioning..$^{70}$ The savaging of Oates's motives as a "witness" and the Whigs' motivation in pursuing popery is typical:

Witnesses I bring, and produce the record

D'ye think th' are perjur'd

'Tis false and absurd,

Wou'd th' Godly [Whigs] hang Papists for interest of picque?

Wou'd a doctor [Oates] swear false for ten pounds a week ${ }^{71}$

This inquisitive mockery became more and more cutting each time the ballad's refrain was repeated at the close of verses detailing ever more ridiculous evidence from the Plot: "The Truth of my story, if any man doubt/ W'have Witnesses ready to swear it all out."72

This recourse to doubt should make us pause and consider what we mean when we label prints like this "propaganda". That label implies an image or text which asserts a line or idea in a positive, bullish, or, perhaps, condensed manner. Horrid Hellish Popish Plot, however, does no such thing. The Plot and, by implication, the Whigs who have made political hay from it, are mocked in a scathing manner; but there is no explicit line in support of James, against Exclusion, or for the church and regime of Charles II. These prints do not ask reader/viewers to assent to anything. Consequently, although it is undoubtedly true that those reader/viewers whom we label "Tory" could have found their views supported in Horrid Hellish Popish Plot, it is equally true that the omissions and silences in the prints suggest that they were not intended to be mere distillations or summations of Tory ideology. They proceeded in a manner which is subtler than "propaganda" suggest. Working by hints and teases, they expected an audience which was visually and politically literate and brought a pronounced familiarity with the Plot trials, and the print surrounding them, to their commentary: indeed, given the volume of 
references to the latter, these prints were clearly produced with the expectation that this knowing audience would have these works (many of which were now several years old) to hand. Leading audiences through such a forensic assault on the Plot suggests that the ultimate aim here was about more than mocking Whig visual culture. These prints questioned what could be known about the Plot.

When contextualised, we might see that rampant questioning according graphic satire a political voice to which "propaganda" does not adequately do justice. In the late seventeenth century - when traditional authorities were increasingly tested - doubt could provoke significant anxiety. As Jack Lynch's study of literary forgeries has shown, outraged reactions to deception focussed less on its immorality than on the epistemological issues raised by hoaxes. It was not that deception was immoral, but that they it was possible which caused consternation. In an age which promoted certainty through historicism, scientific epistemology and a growing confidence in the standard of legal evidence, fraud threatened confidence in the ability to perceive the world accurately and judge what was perceived rationally. ${ }^{73}$ To be confronted with deception was therefore more than to be jolted into reading sceptically: it was to be anxious about how we know. As a sham, Horrid Hellish Popish Plot aimed to raise these anxieties in its audiences. By exposing the Plot as resting on farcical evidence, and then confronting the audience with what should not be there - footnotes on a farce - to mock the conventions of academic truth telling, Horrid Hellish Popish Plot created a discourse upon discourse, forcing an unsettling reflection upon the fabric of convention by ridiculing the authorities - print and the law - which had authenticated this farce and doubting the capacity of those authorities to know the truth. ${ }^{74}$ The result was to paralyze the Plot as a vehicle of political lobbying.

\section{V: The Allure of Satire}


That result was certainly political, but not in the way which "propaganda" - the bellowing of party lines - suggests. It has been argued so far that we must understand graphic satire as a medium with its own intellectual force rather than one which disseminates or distils ideas and ideology developed elsewhere to an audience on the cusp of politics; and that the nature of that intellectual force can be unpicked by paying close attention to the playful manner of graphic satires' engagement with other media (visual, textual and oral), a playfulness which presumed a politically literate audience. This section develops the concept of playfulness as central to the ways in which graphic satire intervened in news culture. Ultimately, prints were a commercial venture: objects which had to entice audiences to purchase and peruse them. ${ }^{75}$ Play was central to this enticement. It rested upon audiences enjoying the delivery of a political point in a skilful, waspish manner which arrested their attention amidst volumes of competing news discourse. It is argued below that Horrid Hellish Popish Plot touched two taboo areas of Restoration culture - laughter and shamming - which was crucial to its political satire being effective. That Horrid Hellish Popish Plot had an afterlife into the later-seventeenth century (while many prints' topicality made them ephemeral) indicates both its success as a commercial venture and the enduring appeal of its sophisticated satire. ${ }^{76}$

The first factor which made Horrid Hellish Popish Plot alluring was the frisson involved in shamming, which had a morally ambiguous status in the late seventeenth century. Its increasing prevalence was in tension with the immorality of deception. The growth of shamming - in fraudulent archaeological finds, hoax travel accounts and political deception - was morally troubling and, as Kate Loveman has demonstrated, caused interrogatory modes of reading - in which texts were routinely challenged - to become a routine aspect of elite identity. ${ }^{77}$ But responses to shamming were not driven by moral outrage alone. Its status was more ambiguous. Shamming was prominent within spheres of genteel sociability like clubs and coffeehouses, precisely the spheres prints like Horrid Hellish Popish Plot inhabited. ${ }^{78}$ Indeed, new verbs - 
"wheedle", "babble", "banter" - were coined in response to its prevalence. "Lying games" - in which tall-tales were told and unmasked - were a mainstay of elite affiliations, and participating in shams - or out-shamming the shammer - was an aspect of humorous sociability. ${ }^{79}$ That lying was morally taboo undoubtedly heightened pleasure taken from these "lying games" by spicing them with a little danger. That taboo pleasure fed back into print. Defoe and Swift responded to sceptical reading practices to deepen their shams' capacity to fool audiences. The literary success of their works rested upon the enticing frisson accrued through manipulation of a morally ambiguous practice. ${ }^{80}$ The appeal of the Horrid Hellish Popish Plot - its power to work on reader/viewers - depended upon exploiting that same taboo. Pleasure was found in being deceived by the print; and, as we have seen, deception ultimately troubled audiences about the status of the Popish Plot by exposing the artifice by which it had been constructed in print.

\section{Detail figure 5.2: The Jesuit Whitebread spanks Thomas Pickering for failing to kill the king.}

\section{Detail figure 5.3: Oates and the other witnesses receive Mass whilst in the Jesuit's employ.}

\section{Detail figure 5.4: Oates and the other witnesses taking the Oath of Secrecy.}

If shamming was one source of Horrid Hellish Popish Plot's alluring frisson, provoking laughter was another. Laughter was a public vehicle of moral ire in the early modern period. Laughter damned its object by suggesting that it was worthy of derision and thus rendered it ridiculous. It was therefore potent, possessing the capacity to withdraw respect from its object, to alter its social status. As such it played important cultural roles. Moral norms were policed by the threat of laughter, with those who breached sexual and cultural mores - cuckolds, scolds 
and adulterers - publicly shamed through charivari or taunting rhymes which restored the patriarchal order by making aberrations from that order outcasts. ${ }^{81}$ Satirical moralising shared the violence of this rough justice: the classical tradition bequeathed to early modern authors the notion that satirical laughter was actively reformative, a means of thrashing vice out of its object by showing it to be ridiculous. ${ }^{82}$ Such was laughter's moral power that it became a potent means of protest. Libel - by which the authorities were shamed through mocking verse - was an established means of popular opposition to state and church. Here mockery was understood to be dangerous. That it was prosecuted as a form of sedition - an attack on the state - indicates how severely unseemly laughter was received. The state defended itself from moral ire by redefining these acts of laughter as immoral. ${ }^{83}$

Whether conceived positively - as reformative satire - or negatively - as corrosive sedition mockery was thus understood to possess considerable agency. That agency must condition how we approach the moral power asserted by prints like Horrid Hellish Popish Plot. At one level, the Jesuit Thomas Pickering having his bottom thrashed by the order's Principal Whitebread is crudely titillating [detail fig 5.2]. But it served to throw the ridiculousness of Oates's account of witnessing this event into relief: if the Plot was real, was this a fitting punishment for fluffing the opportunity to kill the king as Oates asserted Pickering had done ${ }^{84}$ There was, then, a moralistic sting in the tail of these prints' playfulness. ${ }^{85}$ The first two scenes of the second print - which treat Oates attending Mass and being sworn to secrecy about the plot - are cases in point [detail fig $5.3 \& 5.4$ ]. These raised questions about his honesty by stressing that his entire account rested upon his being a traitor and a man prepared to endanger his soul. Humour here is all the more pointed for being subtle: the allusions in these scenes are not explained in the text, and their gibes therefore rested upon a significant degree of visual literacy amongst the print's audience. At Mass Oates and Bedloe flippantly exclaim "mea culpa" (in reference to their apostasy) before an altarpiece depiction of the Judas Kiss - the point being that if, as they 
claimed, these men were prepared to betray the Catholics with whom they had been so closely affiliated, how could they be trusted now? Mockery has added vim in scene two where an altarpiece of the false witnesses stands over Oates and other "witnesses" as they take the Oath of Secrecy by which the Jesuits made them privy to the plot. A footnote spelled out the barb:

This is not meant of any Oath against the Papists, but of their wicked Oath of Secrecy; which though the Doctor [Oates] often took, yet we may charitably believe he never did intend to keep; since he positively assures us he did but counterfeit: he only seemed to be a Papist, but was all the while a True Protestant in his heart. ${ }^{86}$

Oates cut a ridiculous figure as a "Protestant" hero, and laughter here pointed to the immorality of his being styled as such. That laughter rested upon a collusion of audience and print: on reader/viewers being (firstly) fooled by and (subsequently) unravelling the prints' imagery by close-reading of its texts and chasing its wider references. Revelation stimulated appreciation of the graphic cleverness of its play with Whig visual culture. The visual appeal of graphic satire was essential to their intervention in news culture.

\section{Figure 6. George Bickham, Sot's Paradise (1707). Copyright of the British Museum.}

Figure 7. John Bickham, Gaming (c.1700). Copyright of the British Museum.

That playfulness continued to be vital to political prints as graphic culture developed. Medley

prints demonstrate how visual appeal amplified a political point. ${ }^{87}$ Prints like George Bickham's Sot's Paradise (1707) and John Bickham's Gaming (c.1700) were pleasing forms of deceptive play [figs. $6 \& 7.]^{88}$ The exact and deceptively three-dimensional nature of these engravings persuaded viewers (momentarily at least) that they were looking at a pile of printed 
objects scattered as though on a desk. In Sot's Paradise we see a print of a self-portrait of Philippe de Champaigne overlain with an engraved Captain's commendation and a playbill for Edward Ward's 'Sot's Paradise', both of which are partially obscured by a representation of the Presentation of the Virgin. Other images - classical ruins, a pierrot, ornaments, a Gregorian chant, a print of peasants and an illustration to a fable about animals - complete the illusion, the aim of which was to exploit the pleasures of visual deception. Contemporary art theory dramatized the significance of the deceitful first impression. Thus in $1695 \mathrm{Du}$ Fresnoy proclaimed that "the chief end of Painting is to please the eyes....the means of this pleasure is by Deceipt", and viewers of medley prints were encouraged to appreciate, and be delighted by, the skill required to create their visual trap. ${ }^{89}$ Understood as a "Deception Visus" - a virtuoso performance of printmaking - they advertised an engraver's talents and wares to the buying public. Deception might also reveal an underlying moral message, as in the Gaming print, which used humour to chastise viewers about the dangers of gambling. ${ }^{90}$

\section{Figure 8. George Bickham, The Whig's Medley (1711). Copyright of the British Museum.}

In George Bickham's The Whig's Medley (1711) - a satire on Daniel Defoe - that playful appeal had a political end [fig. 8. ${ }^{91}$ Defoe had been punished in the pillory for a libel against High Churchmen and attack on the Tory Henry Sacheverell for deeming pro-Whig sentiment within the Anglican ministry the stiffest test facing the Church. ${ }^{92}$ Once again a series of images appear casually scattered before viewers. Yet those images have polemical coherence: the medley print and political print were brought into playful dialogue to make a polemical point. The central image of Defoe as a self-satisfied figure (advised by the Devil and the Pope) was juxtaposed with a grotesque of his head in the pillory and a roundel of Oliver Cromwell, teasingly placed next to the courtly symbol on the playing card, tainted Defoe by association 
with a reviled anti-monarchical figure. Indeed, reference to the "calves head feast" (a symbol of Charles I's execution) scathingly implied where Defoe's ideas would culminate (bottom left). The inclusion of “A Whig \& a Tory Wrestling” tied this imagery's ideological allegiances into the wider party-political conflict. ${ }^{93}$ This anti-Defoe attack parodied anti-Sacheverell imagery. The central image of Defoe, the Pope and the Devil, for instance, inverted an attack on Sacheverell [fig. 9.] ${ }^{94}$ Whig's Medley's subversive appropriation of this imagery meant that its political force rested upon its audience experiencing multiple deceptions: first, the medley

prints' conventional trick of appearing as a smattering of objects; second, the revelation of those objects' (anti-Defoe) polemical coherence through a succession of barbs across the print; and, third, the realisation that the polemic in question parodied the imagery of its object's (the Whigs) own polemic. Visual deception commented on the nature of political representation: playfulness enhanced its political force.

\section{Figure 9.The High Church Champion \& His Two Seconds (1711). Copyright of the British Museum. The central scene depicts Sacheverell advised by the Pope and the devil.}

Two forms of satiric representation (the medley print and political satire) were thus brought into contact to make a political point. The print's appeal rested upon an appreciation of both its political bite and artistic skill - its polemical thrust and the playful, self-referential nature of imagery were mutually dependent. Late seventeenth century engravers and painters were prone to using visual illusion in the service of political and social commentary, as Dror Wahrman's study of the trompe l'oeul painter Edward Collier had demonstrated. Viewers of Collier's letter racks stuffed with printed ephemera were to take more away than an admiration of the artist's skill: the pleasure found in being fooled was to be followed by consideration of the fact that the objects depicted - newspapers, prints and pamphlets - were equally as deceptive, despite 
their pretence to state the truth and disseminate knowledge. ${ }^{95}$ Horrid Hellish Popish Plot functioned in comparable ways: parodying their opponent's imagery, and deceiving their audiences, to sharpen its polemic bite. As Whig's Medley jutted together aspects of antiSacheverell Whig discourse in the 1710s, so the Horrid Hellish Popish Plot employed a similar disjuncture against Whig anti-Catholic imagery in the 1680s. Appropriation re-positioned Whig imagery for two polemical purposes: to reflect that imagery's associations back upon its authors; and to undermine its political force by exposing the mechanisms by which it worked upon the public. Subjecting audiences to one deception, these prints charged that the imagery they employed had long been the means of another. In this way, the graphic element of graphic satire was central to its intervention in news culture.

\section{Conclusion}

This article has argued that the capacity of graphic satire to intervene in politics rested on a paradox: graphic satire was parasitic on other genres of news for its vocabularies, tropes and motifs; but by appropriating those elements, placing them in new contexts, and putting them to new ends, it nevertheless interpreted what it borrowed into a specific political commentary rather than a simple summation of party ideology which had been developed elsewhere. The manner of graphic satire's engagement with other media has been shown to have been playful, and it has been argued that the frenetic energy of parody, sham and satire were crucial to amplifying a print's political point. Play was vital to subverting the ideology and polemical strategies of other political groups; and to making graphic satire alluring, enticing reader/viewers to purchase and engage with these products in a crowded public sphere. That play was vital to how the author/artist of graphic satire expected audience to engage with their work makes approaching them as "propaganda" or political posters problematic. Those approaches suggest that visual sources were intended for a passive audience, aimed to impart information or ideas, and to do so in a condensed manner. Conversely, the playfulness of 
graphic satire implies that audiences were expected to be active interrogators of news, to arrive at prints with an appropriate knowledge of politics, and yearn to explore the complexity of the issues raised. The teasing and exacting nature of the engagement which prints like Horrid Hellish Popish Plot expected of its reader/viewers rested on a playful subversion of the printed media it cited and the visual media it parodied. ${ }^{96}$ By combining its range of references and criticisms into an acute conceit, prints like Horrid Hellish Popish Plot combined complexity and pith in an alluring manner to spark audience interest: with playful engagement came political power. As Eirwen Nicholson has demonstrated, the emblematic aspects of prints remained vital to graphic satire well into the eighteenth century - confronting reader/viewers with exacting and playful visual strategies as a means of teasing out moral complexities and political absurdities was at the core of printmaking long after the Succession Crisis. ${ }^{97}$

Play, then, was not frivolous. By subjecting audiences to deception and laughter, it could be used to amplify political points, touching on the taboo to create an alluring frisson. Satire had an equally ambivalent position during moments of political unrest. Readily invoked for its capacity to counsel and reform the body politic, that satire was a moral defence against tyranny and therefore a necessary part of political writing was a convention of rhetorical practice. Yet satirising church or state was easily interpreted as a libellous threat which could corrode the ties of respect which bound society together: press freedom during the Succession Crisis was feared precisely because many remembered the social collapse of the 1640 s being triggered by a licentious press. In this context, satirical laughter was dangerous. The case of Stephen College - a Whig supporter executed for treason in 1681 - is revealing. College's authorship of several graphic satires was a prominent part of the evidence presented for his treason: ridiculing church and state was interpreted as violent intent, proof that College had "imagined the king's death."98 One person's "satire" was thus another's "sedition", and the ambivalence towards mockery 
which graphic satire evoked was ultimately the source of its appeal and bite. Those ambivalences were retained - albeit in an altered form - in the eighteenth century. As Mark Hallet and Vic Gatrell have demonstrated, during the eighteenth century graphic satirists strove to be accepted as part of polite society whilst simultaneously cultivating an iconoclastic identity which could not conform to that society's artistic and aesthetic conventions: they were impolite in an age of politeness. ${ }^{99}$ That iconoclasm was the source of graphic satire's power. Playful engagement with norms, mores and politics was at the nub of their alluring capacity to disturb the rhythms of all three.

\footnotetext{
${ }^{1}$ Sharpe, Image Wars; idem, “'So Hard a Text?”; Pierce, Unseemly Pictures; idem, “Anti-Episcopacy and Graphic Satire”; idem, “Artful ambivalence?”; M. Knights, "Possessing the Visual”; Bellany, "Buckingham Engraved" and Champion, "Decoding the Leviathan" in Hunter (ed.), Printed Images; Knoppers, Constructing Cromwell; Griffiths, Print in Stuart Britain; Jones, Print in early modern England: 57-155; A. Globe, Peter
} Stent.

${ }^{2}$ Pierce, "Unseemly pictures".

${ }^{3}$ Fox, Oral and literate culture; Fox \& Woolf (eds.), The spoken word; Harris, Popular Culture in England; Dimmock \& Hadfield (eds.), Popular culture in early modern England; Lamb, Popular culture of Shakespeare.

${ }^{4}$ See Sharpe, "Representations and negotiations"; idem, "The Royal Image".

${ }^{5}$ Raymond, Invention of the newspaper; idem, Pamphlets and Pamphleteering; Halasz, Marketplace of print; Harris, London Crowds; Knights, Politics and Opinion, chapter 6, in particular; Sharpe \& Lake (eds.), Culture and Politics; Dooley, "News and doubt in Early Modern culture?”; "Introduction”, in News Networks in seventeenth century Britain and Europe ed. Raymond: 1-14; Lake \& Pincus (eds.), Politics of the public sphere. ${ }^{6}$ Sharpe, “Celebrating a cultural turn”; Knights, Representation and Misrepresentation. Pocock, Politics, Language and Time, essays 1-4 in particular; idem, "The Concept of a Language"; Skinner, Visions of Politics, vol. 1 , chapters 4-7 in particular.

${ }^{7}$ Porter, "Seeing the Past"; Jordanova, "Image Matters".

${ }^{8}$ See their used in Harris, London Crowds: 125-28, 136-37, 140-44. It should be noted that Prof. Harris was one of the first scholars to take the visual material of this period seriously. All scholars of it owe him a considerable debt of gratitude. 
${ }^{9}$ BM Sat 1080; Harris, Restoration: 249-50. Quotation at 249.

${ }^{10}$ See Morton, "Intensive Ephemera". The Committee responded to highly specific charges in Stephen College's, The Catholick Gamesters (BM Sat 1077) surrounding the prorogation of the first Exclusion Parliament. Both prints made sophisticated comments upon a very specific moment of politics.

${ }^{11}$ Harris, Restoration: 216.

${ }^{12}$ Loveman, Reading Fictions. Cf. Zwicker, "The constitution of opinion”.

${ }^{13}$ For a discussion of this form of reading, see Morton, "Confession or Corruption?"

${ }^{14}$ Marsh, “"The Blazing Torch”, 95-97.

${ }^{15}$ Sharpe, "Representations and Negotiations", passim.

${ }^{16}$ Tapsell, Personal Rule of Charles II

${ }^{17}$ Williams, “Pope-Burning Processions"; Monteyne, Printed Image in early modern London, chapter 4.

${ }^{18}$ Kenyon, Popish Plot; Miller, Popery \& Politics; Hinds, Horrid Popish Plot, passim; Knights, Politics \& Opinion:16-19, 30-35, 122-27, 187-94, 292-98.

${ }^{19}$ As articulated in Oates, A true narrative; Discovery of the Popish Plot. These were updated as events unfolded: Oates, A sermon preached; King 's evidence justifi'd; Greene, Diaries of the Popish Plot:162-240.

${ }^{20}$ HMC Ormonde, 462. Kenyon, Popish Plot: 59, 66-69, 75.

${ }^{21}$ Kenyon, Popish Plot:70; Greene, Diaries of the Popish Plot: 202, 215, 231-33, 236-37, 239.

${ }^{22}$ Marshall, Strange Death; Greene, Diaries of the Popish Plot: 35-39, 47, 53-55, 112, 167, 171, 232; Kenyon, Popish Plot:77-131, 264-70.

${ }^{23}$ Bedloe, Narrative and Impartial Discovery; Bury, True Narrative; A True and perfect relation; The righteous evidence; Prance, True Narrative and Discovery. Kenyon, Popish Plot: 100-116, 122-28, 132-38, 140-78, 199220, 266-70; Greene, Diaries of the Popish Plot, 29, 38-40, 88, 93-94.

${ }^{24}$ Miller, Popery \& Politics:121-53; Tumbleson, Catholicism in the English Protestant Imagination: 69-97. De Krey, Restoration and Revolution, 56-76, 92-105, 110-117, 127-34, 150-53.

${ }^{25}$ I use the term "Succession Crisis" rather than "Exclusion Crisis" to describe the period 1678-83 because the former better captures the range of issues confronted and problems experienced in those years - attempting to exclude the future James II from the throne played a vital role in this crisis, but it was not the only or dominant concern about popery and arbitrary government. For further discussion, see Hutton, Charles II, 357; Scott, Algernon Sidney \& the Restoration Crisis, 9-21; idem "Radicalism and Restoration", 459-60; Knights, Politics \& Opinion, 4-5, 350 . 
${ }^{26}$ Dialogue Between the Pope and a Phanatick, 12; BM Sat 1122; Foxes and Firebrands; Pelling, A Sermon Preached; Knights, “Faults of Both Sides”, 87-111; Knights, Representation, 238-48; idem, Opinion,184-90; Harris, Crowds, 133-45; Tumbleson, Catholicism in the English Protestant Imagination, chapters 3 \& 4; Krey, Restoration and Revolution,134-59, 165-76; Miller, Popery \& Politics,169-82. See also Glassey (ed.) Reigns of Charles II and James VII and II, chapters 4, 7, 9 for a discussion of the role of fear and memory in this period.

${ }^{27}$ Knights, Representation and Misrepresentation, 3-4, 28-33, 209-10, 218-19, 236-48, 272-89, 298-302.

${ }^{28}$ Shapin, Social history of truth; Williams, Poetry and the creation of Whig literary culture.

${ }^{29}$ Mason, “The Annual Output of Wing-Listed Titles 1649-1684”, 219-20; Weber, Paper Bullets, passim; Spurr, England in the 1670s, 165-70.

${ }^{30}$ Knights, Representation and Misrepresentation,3-12, 211, 245-48, 274-79, 284-80; Camden Miscellany, 26, 147.

${ }^{31}$ South, Twelve Sermons, sermon ix, "The Fatal Imposture and Force of Words", quoted in Knights, Representation and Misrepresentation: 211.

${ }^{32}$ Morton, Glaring at Antichrist, chapter 4.

${ }^{33}$ Morton, "Intensive Ephemera".

${ }^{34}$ The figures cited here are by no means exhaustive - the images reappear in a range of media. Other scenes became equally iconic.

${ }^{35}$ BM Sat 1064;1072; 1067; 1088; 1077; 1084. For more on The Catholick Gamesters see Morton, 'Intensive Ephemera'.

${ }^{36}$ BM Sat 1067.

${ }^{37}$ Protestants Vade Mecum, passim.

${ }^{38}$ For details of what the images depict, see details of the print at: www.britishmuseum.org/research/collection_online/

${ }^{39}$ Accounts cited: Part one: Tryals of Green, Berry, \& Hill; Tryals of Ireland, Pickering, and Grove; Oates, True narrative; Tryall of Langhorn; Tryal of Coleman. Part two (in addition to those cited above): Tryals of Wakeman.

${ }^{40}$ For a similar approach to parody see Grimes, "Verbal Jujitsu”, 173-84.

${ }^{41}$ Harris, Restoration, chapters 4 \& 5.

${ }^{42}$ Tapsell, Personal Rule of Charles II, 31-63 in particular. 
${ }^{43}$ Harris, London Crowds, 132; Haley, First Earl of Shaftesbury, chapters 21-30; Miller, Charles II, 348-50;

Allen, “The Role of London Trained Bands”, 287-303; Luttrell, Historical Relation I, 199, 232, 242-43, 251, 271-72.

${ }^{44}$ Speck, Reluctant Revolutionaries, 135; Harth, Pen for a Party, 80-84, 149-53.

${ }^{45}$ Cressy, Bonfires and Bells, chapters 9-11.

${ }^{46}$ Knights, Politics \& Opinion, 227-42, 258-305, 329-44; Harris, Restoration, 266-92; Loyal Protestant Intelligencer, nos. 20 (14 May 1681), 22 (21 May 1681), 46 (13 Aug 1681).

${ }^{47}$ Hinds, Horrid Popish Plot; Goldie, “Roger L'Estrange's Observator ”. See also Harth, Pen for a Party, passim; Harris, London Crowds, chapter 6; Knights, Politics \& Opinion, 166-8.

${ }^{48}$ Tory newspapers included: True Domestick Intelligence (June 1679-May 1680, published by Nathaniel Thompson); L'Estrange's Observator (13 April 1681 to March 1687); Thompson's Loyal Protestant and True Domestick Intelligence (247 issues 9 March 1681-20 March 1683); The Weekly Discovery of the Mystery of Iniquity (5 February-27 August 1681); and Heraclitus Ridens (1 February 1681-22 August 1682). The bi-weekly London Gazette acted as the government's official news vehicle. O’Malley, "Religion and the Newspaper Press", 25-46.

${ }^{49}$ Observator, I, ‘To The Reader’; no. 1 (13 April 1681); III, nos. 151 (6 March 1685/6), 153 (10 March. 1685/6), 206 (4 Sept 1686). Goldie, "Restoration Political Thought”, 12-35; Plain Dealing; Nalson, Complaint of Liberty, 5; L'Estrange, Character of a Papist in Masquerade.

${ }^{50}$ Horrid Hellish Popish Plot - part 1. BM Sat 1092.

${ }^{51}$ Horrid Hellish Popish Plot - part 1 BM Sat 1092 (scene 2); Protestants vade mecum, 54 \& 58; BM Sat 1064, 1067 (scene 5), 1088; BM O’D4, Plot in a Dream, 150.

${ }^{52}$ Horrid Hellish Popish Plot - part 2 BM Sat 1093. Verse VI. Verse VII notes how much of the witnesses' evidence is heavily contradicted by witnesses for the defence.

${ }^{53}$ Horrid Hellish Popish Plot - part 1 BM Sat 1092, verse II.

${ }^{54}$ The footnotes cite Tryal of Green, Hill, Gerald and Kelly:16-18, 20, 31, 35 \& 69 and refer reader-viewers to the Coroner's Inquest - if the Jesuits wanted to make Godfrey's murder look like a robbery, why did they leave so much money about his person?

55 The satire was rich. BM Sat 1093 verses I \& II alone refer to: that such a "secret" plot was known by so many; that Catholics would use such known rogues as messengers to facilitate it; that Oates claimed to have seen a hundred letters, many of which travelled by post, and yet not one had come to light. Verse III mocked the 
huge sums of money supposedly being moved about unseen (even by Oates). References cited, Tryal of Coleman, 21-24, 40.

${ }^{56}$ Horrid Hellish Popish Plot - part 2 BM Sat 1093; See Tryal of Coleman, 30; Tryal of Wakeman, 30, 55.

${ }^{57}$ Horrid Hellish Popish Plot - part 1 BM Sat 1092 (scene 5); heavily reliant on Tryals of Green, Berry \& Hill, 18-20.

${ }^{58}$ Horrid Hellish Popish Plot - part 1 BM Sat 1092 (scene 4). The Key (D) expands the farce: "We may well suppose that the devil help'd then when they passed so close by the Centry: and we may be more assured, they could not without some Diabolical Art (after so many days being dead) bend his Legs to fit in the Chair, then to stretch them out stiff again, as he was found on Primrose Hill [referring to scene 5].” The references cite Tryals of Green, Hill, Gerald \& Kelly, 20, 35, 36, 69. Prance claimed not to have seen any sentry - the evidence given Wright, Trollop and Collet (69), however, refuted the notion of any sedan leaving Somerset House on the night which Prance alleged (thus the devil shielding the sentries' eyes in the scene). The verse mocked "they carried him [Godfrey] out in an invisible chair."

${ }^{59}$ Horrid Hellish Popish Plot - part 1 BM Sat 1092 (scenes 8 \& 10, verses VIII-IX); cites Oates, True Narrative, $47 \& 58$.

${ }^{60}$ Horrid Hellish Popish Plot - part 1BM Sat 1092 (scene 12).

${ }^{61}$ Horrid Hellish Popish Plot - part 1 BM Sat 1092; Tryall of Langhorn, 20, 23; Tryal of Coleman, 22-23.

${ }^{62}$ Raymond, Pamphlets and Pamphleteering, 210-215, 350-1.

${ }^{63}$ Lake, “Anti-popery”, 72-106. Weiner, “The Beleaguered Isle”, 27-62.

${ }^{64}$ Milton, Catholic and Reformed, chapters 1-7; Lake, “Anti-puritanism”, 80-97.

${ }^{65}$ Sowerby, "Opposition to anti-Popery".

${ }^{66}$ L'Estrange History of the Plot; Narrative of the plot; A further discovery. These were seen as very detrimental to prosecution of the plot. See A Collection of Speeches and Debates in the Houses of Commons, A2.

L’Estrange was later deposed as a Catholic, Hinds, Horrid Popish Plot, 164.

${ }^{67}$ Harris, Restoration, 219-220; L’Estrange, Observator, i, 58, 1/10/1681; i, 160 24/6/1682; idem, Narrative of the plot, 21; Brief History, i, 5, ii, 89. Many Tory writers suggested that "Whig" views - sovereignty of the people, for example - were Catholic in origin. See Pelling, Sermon Preached, 13-14; Hickes, Discourse of the Soveraign Power. Tory literature also suggested that by aiming to destroy monarchy, Exclusion was the ultimate aid to the Pope: Observator, I, no 318 (12 April 1683); Heraclitus Ridens, no. 7 (15 March 1681), 2 (8 Feb 1681), 4 (22 Feb 1681); Advice to the Men of Shaftesbury (London, 1681): 1-2. 
${ }^{68}$ BM Sat 1093 (scene 12). Plot in A Dream,150; BM Sat 1067;1088, scene IV;1077;1064;1114. The print criticizes the legal system (verse VIII) which leaned on the jury to find the Jesuits guilty, and balances suspicion of their guilt with mockery of the (anti-Catholic) view that the Pope held such immense control over men whose lives were in danger (verse IX).

${ }^{69}$ Harris, Restoration, chapter 4. L'Estrange, Character of a Papist; Nalson, Character of a Rebellion; Plea for Succession, 3-4; Plain Dealing; Observator, I, no. 379 (23 Jul. 1683); Grey, Debates in the House of Commons, VII, 243-48, 402-9, 450-51.

${ }^{70}$ Horrid Hellish Popish Plot - part 1 BM Sat 1092.

${ }^{71}$ Horrid Hellish Popish Plot - part 1 BM Sat 1092. “Ten pounds a week” refers to Oates's state pension.

${ }^{72}$ Horrid Hellish Popish Plot - part s 1 \& 2 BM Sat 1092 \& 1093.

${ }^{73}$ Lynch, Deception and Detection

${ }^{74}$ We might see these prints are pieces of nonsense literature. See Stewart, Nonsense: Aspects of Intertextuality; Ping, Meaningful Nonsense. Bertelsen, Nonsense Club has demonstrated how the nonsense literature of Churchill and Thornton made a considerable contribution to Wilkesite propaganda in comparable ways. 75 This is particularly significant given the price of engravings. See Watt, Cheap Print, 140-41 and Nicholson, “Consumers and Spectators", 5-21.

${ }^{76}$ Griffiths, Print in Stuart Britain, cat. 201. That these prints were entered in the term catalogue in 1685, three years after their initial publication, suggests commercial popularity.

${ }^{77}$ Loveman, Fictions, chapters $1,4 \& 5$.

${ }^{78}$ Pincus, “Coffee Politicians Does Create”, 807-34. Hallet, Spectacle:16-19, 142-43 for the reading space of prints.

${ }^{79}$ Loveman, Reading Fictions, 68.

${ }^{80}$ Ibid, chapters $6 \& 7$

${ }^{81}$ Ingram, "Ridings and the 'reform of popular culture"”, 79-113; Thomas, "The place of laughter", 77-81.

${ }^{82}$ Dryden, Satyr, 62-69; Raffield, Images and Cultures of Law, 35-49 discusses the points of contact between poets and lawyers in using rhetoric to create powerful images of virtue; Skinner, "Hobbes and the classic theory of laughter", 142-76; Farley-Hills, Benevolence of laughter, introduction and chapter 1 in particular; Manning, "Theological Enlightenments \& Ridiculous Theologies".

${ }^{83}$ The literature is vast, but see Bellany, “A Poem on the Archbishop's Hearse”, 137-64.

${ }^{84}$ Horrid Hellish Popish Plot - part 2 BM Sat 1093, scene 7, citing Tryal of Ireland: 24-25. 
${ }^{85}$ Horrid Hellish Popish Plot - part 2. BM Sat 1093; citing Tryal of Stafford: 123.

${ }^{86}$ Horrid Hellish Popish Plot - part 2. BM Sat 1093.

${ }^{87}$ Hallet, "The Medley print ", 214-37.

${ }^{88}$ BM, J, F. 51. For other medley prints see; John Sturt, The May-Day Country Mirth (1706), BM 1896,0501.1360; The Bubblers Medley (1720), BM 1868,0808.3486.

${ }^{89}$ Du Fresnoy, Painting, xxii.

${ }^{90}$ British Museum 1896,0501.1358. This print depicts the 5 of Clubs on top of a scene of Harlequin beating Scaramouche following a game of cards. This is in turn placed on top of a bill warning that gambling "Quarrels create....Oaths and lies are oft the consequence/ And Murders, sometimes, follow loss of Pence." Humour follows the association of these parts as reader/viewers descend the pile of objects.

${ }^{91}$ BM Sat 1571. Defoe had become infamous following his satire on High Church positions against dissenters - The Shortest Way with Dissenters (London, 1732) - which suggested that all dissenters should be killed. I am indebted to Hallet, Spectacle of Difference, 37-40, 46-55 for information about The Whig's Medley.

${ }^{92}$ Speck, "Current State of Sacheverell Scholarship", 16-27; Knights, Faction Displayed.

${ }^{93}$ BM Sat 1571.

${ }^{94}$ BM Sat 1498;1512; 1068;1501. These recycled ideal portraits of Sacheverell such as a mezzotint by Pieter Schenk, after Thomas Gibson (1710) held in the British Museum.

${ }^{95}$ Wahrman, Mr Collier's Letter Racks, pp. 6-8, 9-18, 227-33 in particular.

${ }^{96}$ I have argued elsewhere that printmakers created satires with a "knowing viewer" in mind: a politically literate audience which did not expect to be informed by prints, but rather brought considerable knowledge of day-to-day politics to them. This allowed satirists to be more teasing and allusive, facilitating a more intimate author-audience relationship and consequently a sophisticated political satire. See Morton, "Intensive Ephemera". For prints which relied heavily on visual play, see The Catholick Gamesters (1680) BM Sat 1077 and The Committee (1680) BM Satires 1081 (which understood its audience to be extraordinarily politically literate).

\footnotetext{
${ }^{97}$ Nicholson, "Emblem v. Caricature".

${ }^{98}$ Morton, Glaring at Antichrist (forthcoming), chapter 8.

${ }^{99}$ Hallet, Spectacle of Difference:1-2; Gatrell, City of Laughter, 1-19 \& 574-95.
}

\section{Bibliography}


Allen, D.F. "The Role of London Trained Bands in the Exclusion Crisis 1678-81", English Historical Review, 87 (1972): 287-303.

Bedloe, William A narrative and impartial discovery of the horrid Popish Plot. London: Robert Boulter, John Hancock, Ralph Smith, and Benjamin Harris. 1679.

Bellany, Alastair, "Buckingham Engraved: Politics, Print and Images and the Royal Favourite in the 1620s" in Printed Images in Early Modern Britain ed. Michael Hunter. 215-35.

Aldershot: Ashgate 2010.

, “A Poem on the Archbishop's Hearse: puritanism, libel and sedition after

the Hampton Court Conference”, Journal Of British Studies, 34 (1995): 137-64.

Bertelsen, Lance, The Nonsense Club: Literature and popular culture, 1749-64. Oxford: Oxford University Press, 1986.

Blount, Charles, An Appeal from the Country to the City for the preservation of His Majesties person, liberty, property, and the Protestant Religion. London: T. Davis. 1679.

Bury, John, A true narrative of the late design of the papists to charge their horrid plot upon the Protestants by endeavouring to corrupt Captain Bury and Alderman Brooks of Dublin. London: Dorman Newman. 1679.

Champion, Justin, "Decoding the Leviathan" in Printed Images in Early Modern Britain ed. Michael Hunter. 255-75. Aldershot: Ashgate, 2010.

A Collection of scarce and valuable tracts, 13 volumes (London, 1809-15).

A Collection of Speeches and Debates made in the Honourable Houses of Commons. London: Francis Smith. 1681.

Cressy, David. Bonfires and Bells: national memory and the Protestant calendar in Elizabethan and Stuart England. London: Weidenfeld \& Nicolson. 1989.

De Krey, Gary. Restoration and Revolution: a political history of Charles II and the Glorious Revolution. Basingstoke: Palgrave MacMillan. 2007.

A Dialogue Between the Pope and a Phanatick, Concerning Affairs in England. London: John Kidgell. 1680.

Dimmock, Matthew \& Hadfield, Adrian (eds.). Popular culture in early modern England. Aldershot: Ashgate. 2009.

Dooley, Brendan \& Baron, S.A. The Politics of Information in Early Modern Europe. London/New York: Routledge. 2007.

Dryden, John, Discourse on Satyr. London. 1692. ,Works, ed. J. Mitford. London: Aldine ed. of the Brit. Poets. 1836.

Du Fresnoy, Charles, The Art of Painting (London: Bernard Lintott. 1716. 
Farley-Hills, David. The benevolence of laughter: comic poetry of the Commonwealth and Restoration. London: Macmillan. 1974.

Fox, Adam. Oral and literate culture in Britain, 1500-1700. Oxford: Oxford University Press. 2000.

Fox, Adam \& Woolf, Daniel (eds.), The spoken word: oral culture in Britain 1500-1800. Manchester: Manchester University Press. 2002.

Foxes and Firebrands; or, A specimen of the Danger and Harmony of Popery and Separation. London: Awnsham Churchill. 1680.

Franklin, Alexandra. "Making Sense of Broadside Ballad Illustrations in the Seventeenth and Eighteenth Centuries". In Studies in Ephemera. Text and Image in Eighteenth-Century Print, edited by Kevin D. Murphy and Sally O’Driscoll, 169-93. Lewisburg. Bucknell University Press, 2013.

Gatrell, Vic, City of Laughter: Sex \& Satire in Eighteenth-Century London. London: Atlantic Books. 2006.

Globe, Alexander, Peter Stent, London Printseller, c. 1642-1665: Being a Catalogue Raisonné of His Engraved Prints and Books with an Historical and Bibliographical Introduction. Vancouver: University of British Columbia Press. 1985.

Goldie, Mark. "Roger L'Estrange's Observator and the Exorcising of the Plot" in Roger L'Estrange and the Making of Restoration Culture, ed. A. Dunan-Page \& B Lynch. 67-88. Aldershot: Ashgate. 2008.

, "Restoration Political Thought" in Reigns of Charles II and James VII and II ed. L.K.J. Glassey. 12-35. Basingstoke: Palgrave MacMillan. 1997.

Greene, Douglas, Diaries of the Popish Plot. Delmar, NY: Scholars' Facsimiles \& Reprints. 1977.

Grey, A. Debates in the House of Commons 1667-94, 10 vols. London. 1769.

Griffiths, Anthony, The Print in Stuart Britain 1603-1689 . London: British Museum. 1998.

Grimes, Kyle, "Verbal Jujitsu: William Hone and the Tactics of Satirical Conflict" in The Satiric Eye: Forms of Satire in the Romantic Period, ed. S.G. Jones. 173-84. New York/Basingstoke: Palgrave MacMillan. 2003.

Haley, K.H.D, The First Earl of Shaftesbury. Oxford: Clarendon Press.1968.

Hallett, Mark, The Spectacle of Difference: graphic satire in the age of Hogarth. New Haven: Yale University Press. 1999.

214-37. , “The Medley print in eighteenth century London”, Art History, 20 (1997):

Halasz, Antonia. The marketplace of print: pamphlets and the public sphere in early modern England. Cambridge: Cambridge University Press. 1997. 
Harth, Phillip. Pen for a Party: Dryden's Tory Propaganda and its Contexts. Princeton: Princeton University Press. 1993.

Harris, Tim. Restoration: Charles II and his Kingdoms. London: Penguin. 2006.

MacMillan. 1995.

Popular Culture in Early Modern England, 1500-1850. Basingstoke: Palgrave London Crowds in the reign of Charles II: propaganda and politics from the Restoration until the Exclusion Crisis. Cambridge: Cambridge University Press. 1987.

Hickes, George, Discourse of the Soveraign Power. London: John Baker. 1682.

Hinds, Peter, “The Horrid Popish Plot": Roger L'Estrange and the Circulation of Political Discourse in Late Seventeenth-Century London. Oxford: Oxford University Press. 2010.

Hutton, Ronald. Charles II: King of England, Scotland and Ireland. Oxford: Oxford University Press. 1989.

Ingram, Martin, "Ridings, rough music, and the "reform of popular culture" in early modern England”, Past \& Present, 105 (1984): 79-113.

Jones, Malcolm. The Print in early modern England: an historical oversight. New Haven: Yale University Press. 2010.

Jordanova, Ludmilla. “Image Matters”, Historical Journal 51 (2008), 777-91.

Kenyon, John. The Popish Plot. London: Heinemann. 1972.

Knights, Mark, Faction Displayed: reconsidering the impeachment of Dr. Henry Sacheverell. Parliamentary History Book Series. 2012.

"Possessing the Visual: The Materiality of Visual Print Culture in Later Stuart Britain" in Material readings of early modern culture: texts and social practices, 1580-1730, ed. J. Daybell \& P. Hinds. 85-122. New York: Palgrave MacMillan. 2010.

Representation and Misrepresentation in later Stuart Britain: partisanship and political culture. Oxford: Oxford University Press. 2005.

"Faults of Both Sides: The Conspiracies of Party Politics under the Later Stuarts" in Conspiracies and Conspiracy theory in early modern Europe: from the Waldensians to the French Revolution, ed. B. Coward and J. Swann. 87-111. Aldershot: Ashgate. 2004.

Press. 1994.

Politics and Opinion in Crisis 1678-81. Cambridge: Cambridge University

Knoppers, Laura. Constructing Cromwell: ceremony, portrait and print, 1645-61. Cambridge: Cambridge University Press. 2000.

Lake, Peter. "Anti-puritanism: the structure of a prejudice" in Religious politics in postReformation England: essays in honour of Nicholas Tyacke (Studies in modern British 
religious history, 13) ed. Kenneth Fincham, \& Peter Lake. 80-97. Woodbridge: Boydell. 2006.

"Anti-popery: the structure of a prejudice" in Conflict in early Stuart England, ed. A. Hughes \& R. Cust. 72-106. London/New York: Longman. 1989.

Lake, Peter \& Pincus, Steve (eds.), The politics of the public sphere in early modern England. Manchester: Manchester University Press. 2007.

Lamb, Mary Ellen, The popular culture of Shakespeare, Spenser and Jonson. London: Routledge. 2006.

L'Estrange, Roger, Brief History of the Times. London. Charles Brome. 1687. , The Character of a Papist in Masquerade. London: J. Graves. 1681. , An account of the Growth of Knavery. London: Henry Brome. 1681. , The history of the Plot. London: Henry Brome. 1679. , Narrative of the plot. London: Joanna Brome. 1680. , A further discovery of the plot. London: Henry Brome. 1680.

Loveman, Kate, Reading Fictions 1660-1740. Aldershot: Ashgate. 2008.

Luttrell, Narcissus, A Brief Historical Relation of State Affairs, 1678-1714, 6 vols. Oxford: Oxford University Press. 1857.

Lynch, Jack, Deception and Detection in eighteenth-century Britain. Aldershot: Ashgate. 2008.

Manning. David. "Theological Enlightenments and Ridiculous Theologies: Contradistinction in English Polemical Theology', in Brett C. McInelly (ed.), Religion in the Age of Enlightenment: Volume 2 209-41. (New York: AMS Press, 2010).

Marsh, Christopher. “"The Blazing Torch': New Light on English Balladry as a Multi-Media Matrix", The Seventeenth Century, 30 (2015), 95-116.

Marshall, Alan, The Strange Death of Edmund Godfrey: plots and politics in Restoration London Stroud: Sutton. 1999.

Mason, W.G. "The Annual Output of Wing-Listed Titles 1649-1684”, The Library, 39 (1974): 219-220.

Miller, John, Charles II. London: Weidenfeld \& Nicolson. 1991. Press. 1973.

Popery and Politics in England, 1660-1688. Cambridge: Cambridge University

Milton, Anthony. Catholic and Reformed: The Roman and Protestant Churches in English Protestant Thought, 1600-1640. Cambridge: Cambridge University Press. 1995.

Monteyne, Joseph. The Printed Image in Early Modern London: Urban Space, Visual Representation and Social Exchange. Aldershot: Ashgate. 2007. 
, "Intensive ephemera: the visual culture of 'news' in Restoration London" in

News in Early Modern Europe: Currents and Connections, ed. S. Davies \& P. Fletcher. 11540. Leiden: Brill. 2014.

Morton, Adam. "A Product of Confession or Corruption? The Common Weales Canker Worms (c.1625) and the progress of sin in early modern England" in Adam Morton et al (eds.), Crosscurrents in Religious Imagery 135-64. Farnham: Ashgate. 2014.

O'Malley, T "Religion and the Newspaper Press 1660-1685: A Study of the London Gazette" in The Press in English Society from the Seventeenth to the Nineteenth Centuries, ed. M. Harris \& A. Lee . 25-46. London: Associated University Presses. 1986.

Nalson, John, Complaint of Liberty and Property against Arbitrary Government. London: Robert Steele 1681. , The Character of a Rebellion. London: Benjamin Tooke. 1681.

Nicholson, Eirwen, "Consumers and Spectators: The Public of the Political Print in eighteenth-century England”, History, 81 (1996), 5-21.

, "Emblem v Caricature: A Tenacious Conceptual Framework" in Emblems and Art History ed. Alison Adams and Laurence Grove. 141-67. Glasgow: Department of French, University of Glasgow. 1996.

Oates, Titus, A true narrative; The Discovery of the Popish Plot, Being the Several Examinations of Titus Oates. London. 1679.

A sermon preached at St. Michael Wood-street at the request of some friends.

London: H. Hills. 1679.

, The King's evidence justifi'd, or, Doctor Oates's vindication of himself. London: Jonathan Edwin. 1679. Cockerill. 1679.

, A true narrative of the horrid plot. London: Thomas Parkhurst and Thomas

Pelling, Edward, A Sermon Preached On the Anniversary of that Most Execrable Murder of K. Charles the First, Royal Martyr. London: Joanna Broome. 1682.

Pierce, Helen, Unseemly Pictures: Graphic Satire and politics in early modern England. New Haven: Yale University Press. 2009.

47, (2004), 809-48

"Anti-Episcopacy and Graphic Satire in England, 1640-45”, Historical Journal,

, "Artful ambivalence? Picturing Charles I during the Interregnum" in Royalists and Royalism during the Interregnum, ed. J. McElligott \& D.L. Smith. 67-87. Manchester: Manchester University Press. 2010.

"Unseemly pictures: political graphic satire in 1620s England", The British

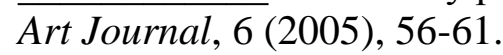


Pincus, Steve, “Coffee Politicians Does Create': Coffeehouses and Restoration Political Culture", Journal of Modern History, 67, (1995), 807-34.

Ping, Charles, Meaningful Nonsense. Philadelphia: Westminster Press. 1966.

Plain Dealing; Or, A Second Dialogue between Humphrey and Roger. London: T.B. 1681.

Plea for Succession in opposition to popular Exclusion. London: Walter Davis. 1682.

The Plot in a Dream. London: John Hancock and Enoch Prosser. 1682.

Pocock, John. G. A, Politics, Language and Time: Essays on Political Thought and History. Chicago: University of Chicago Press. 1989.

Poems On Affairs of State, ed. Geoffrey de Forest Lord, 7 vols., New Haven: Yale University Press. 1963-75.

Popery and Tyranny, or, the Present State of France. London: M.P. 1679.

Porter, Roy, "Seeing The Past", Past \& Present 118 (1988): 186-205.

Prance, Miles, A true narrative and discovery of several very remarkable passages relating to the horrid popish plot. London: Dorman Newman. 1679.

The Protestants Vade Mecum, or, Popery displayed in its proper colours. London: Daniel Browne, Sam. Lee, and Daniel Major. 1680.

Raffield, Paul Images and Cultures of Law in Early Modern England. Cambridge: Cambridge University Press. 2004.

Raymond, Joad, News networks in seventeenth century Britain and Europe. London: Routledge, 2006 , Pamphlets and Pamphleteering in early modern England. Cambridge: Cambridge University Press. 2003. , The invention of the newspaper: English newsbooks 1641-49. Oxford/New York: Oxford University Press. 1996.

The righteous evidence, witnessing the truth. London: Phillip Brooksby. 1680.

A Scheme of Popish Cruelties, or, What We Might Expect Under a Popish Successor. London: N. Tomlinson. 1681.

Scott, Jonathan, Algernon Sidney and the Restoration Crisis. Cambridge: Cambridge University Press. 1991. ,"Radicalism and Restoration”, Historical Journal, 31 (1988)

Shapin, Steven, A Social history of truth: civility and science in seventeenth-century England. Chicago/London: Chicago University Press. 1994. 
Sharpe, Kevin, Image Wars; promoting kings and commonwealths in England, 1603-1660 (New Haven: Yale University Press. 2010.

, “'So Hard a Text?’: Images of Charles I”, Historical Journal, 43, (2000), 383-

406.

, "The Royal Image: an afterword" in The Royal Images: representations of

Charles I, ed. T.N. Corns. 288-309. Cambridge: Cambridge University Press. 1999.

, "Representations and negotiations: texts, images and authority in early modern

England: an historiographical overview", Historical Journal 42 (1999): 853-81.

"Celebrating a cultural turn: political culture and cultural politics in early modern England", Journal of Early Modern History, 1, (1997): 344-68.

Sharpe, Kevin \& Lake, Peter, (eds.), Culture and Politics in Early Modern England. Houndmills: MacMillan. 1994.

Skinner, Quentin, "Hobbes and the classic theory of laughter", in his Visions of politics, vol. 3: Hobbes and Civil Science. Cambridge: Cambridge University Press. 2002.

, Visions of Politics, vol. 1. Cambridge: Cambridge University Press. 2002.

Smith, Bruce R. The Acoustic World of Early Modern England: Attending to the O-Factor. Chicago: Chicago University Press, 1999.

South, Robert. Twelve Sermons Preached upon Several Occasions. London: H. Hall. 1679.

Speck, William. A, "The Current State of Sacheverell Scholarship", Parliamentary History, 31 (2012).

, Reluctant Revolutionaries: Englishmen and the Revolution of 1688.

Oxford/New York: Oxford University Press. 1988.

Sowerby. Scott, "Opposition to Anti-Popery in Restoration England", Journal of British Studies 51 (2012), 26-49.

Spurr, John, England in the 1670s: the masquerading age. Malden: Blackwell. 2000.

Stephens, F. G \& George, M.D (eds.) Catalogue of Political and Personal Satires in the Department of Prints and Drawings in the British Museum, 11 vols. London: British Museum. 1870.

Stewart, Susan, Nonsense: Aspects of Intertextuality in Folklore and Literature. Baltimore/ London: John Hopkins University Press. 1980.

Tapsell, Grant, The Personal Rule of Charles II, 1681-85. Woodbridge. Boydell. 2006.

Thomas, Keith, "The place of laughter in Tudor and Stuart England", Times Literary Supplement 21. Jan. 1977: 77-81.

A True and perfect relation of the wicked and bloody plot that was conspired against His Majesty, and the alteration of the Protestant religion. London: Lawrence White. 1679. 
The tryal of Edward Coleman, Gent for conspiring the death of the King, and the subversion of the government of England and the Protestant religion, November the 28th, 1678. London: John Bradford. 1678.

The tryals of Sir George Wakeman, Barronet, William Marshall, William Rumley, and James Corker, Benedictine monks, for high treason, for conspiring the death of the King, subversion of the government, and Protestant religion, 18th of July, 1679. London: H. Hills. 1679.

The tryall of Richard Langhorn, Esq for conspiring the death of the King, subversion of the government, and Protestant religion, 14th of June, 1679 (London, 1679).

The tryals of Robert Green, Henry Berry, \& Lawrence Hill for the murder of Sr. Edmondbury Godfrey (London, 1679).

The tryals of William Ireland, Thomas Pickering, and John Grove, for conspiring to murder the King, December the 17th 1678. London: Robert Pawlet. 1678.

Tumbleson, Raymond, Catholicism in the English Protestant Imagination: Nationalism, Religion and Literature, 1660-1714. Cambridge: Cambridge University Press. 1998.

Vox Populi, Vox Dei. London: T.B. 1681.

Walsham, Alexandra, "Impolitic Pictures: Providence, History and Iconography of Protestant Nationhood in Early Stuart England" in The Church Retrospective: Studies in Church History, 33 ed. R. Swanson (1997): 403-24

Wahrman, Dror, Mr. Collier's Letter Racks: A Tale of Art \& Illusion at the Threshold of the Modern Information Age. Oxford: Oxford University Press. 2012.

Watt, Tessa, Cheap Print and Popular Piety, 1550-1640. Cambridge: Cambridge University Press. 1991.

Weber, Harold, Paper Bullets; Print and Kingship under Charles II (Kentucky, 1996)

Weiner, Carol, Z. "The Beleaguered Isle: A Study of Elizabethan and Jacobean AntiCatholicism”, Past \& Present, 51, (1971): 27-62.

Williams, Abigail. Poetry and the creation of a Whig literary culture, 1681-1714. Oxford: Oxford University Press. 2005.

Williams. Sheila. "The Pope-Burning Processions of 1679, 1680 and 1681", Journal of the Warburg and Courtauld Institutes 21 (1958), 104-18.

Zwicker, Steven. "The constitution of opinion and the pacification of reading" in Reading, Society and politics in early modern England, ed. K.M. Sharpe \& S. Zwicker. 295-316. Cambridge: Cambridge University Press. 2003. 